\title{
Towards Less Disastrous Result from Earthquakes in the Developing Countries
}

\author{
Eltayeb Hassan Onsa ${ }^{1}$, PhD.
}

\section{Abstract}

During the past two decades, natural disasters have claimed millions of human lives and made more than one billion of people homeless or sick ${ }^{[7]}$. Most of these victims were from developing countries. Earthquakes are one of the natural disasters that strike with little or no warning. Experience with catastrophic earthquakes has shown that demolition and damage of building and structures, which usually have inadequate level safety, cause the human losses and injuries.

This paper reviews the earthquake phenomenon. It defines the main parameters of earthquakes and earthquake engineering. The paper recommends a procedure to be followed by some of the developing countries that lies within seismicprone regions. Special reference is made to the Sudan experience. Sudan has stepped forwards, in the last few years, towards establishment of macro seismic zoning of Sudan and adjacent area and towards the conclusion of suitable seismic design for the Sudan. The paper also recommends updated design provisions which can be adopted for Sudan and other developing countries.

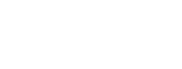

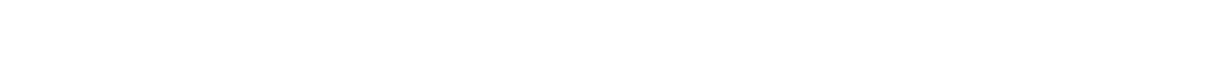

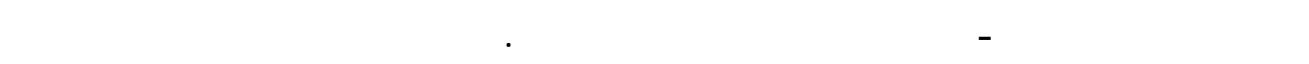
التي تضرب الأرض بطهن إنذار. ومن ملافلة الزلازل المدمرة الثي حثت يتضح لن الضحليا من النالس وقهوا

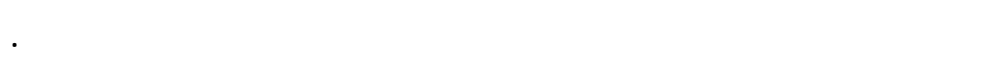

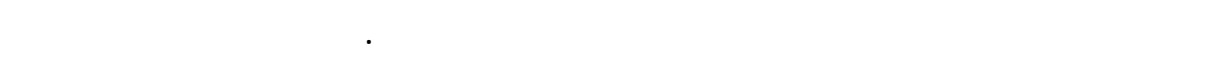

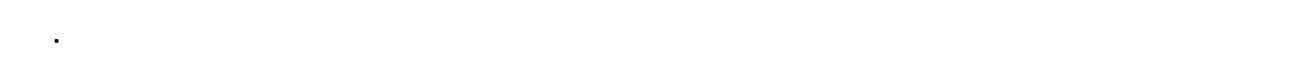

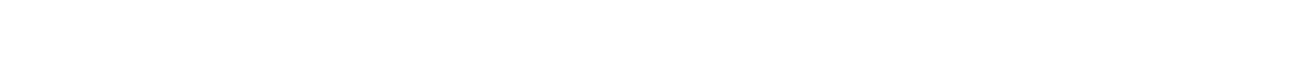

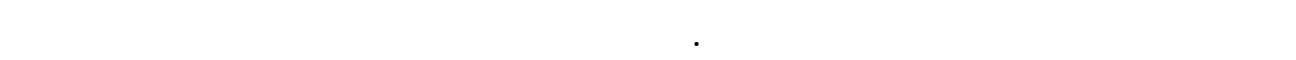

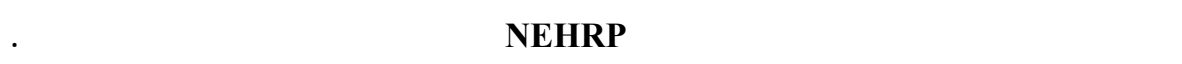

Keywords

Earthquake, Disasters, Seismic zoning, Seismic design of structures, NEHRP.

\footnotetext{
${ }^{1}$ Faculty of Engineering Sciences, Omdurman Islamic University, E-mail: eonsah@gmail.com
} 


\section{Introduction}

An earthquake is an inevitable transient motion, or a series of motions, of the ground orientation in a limited region and spread from there in all direction. Systematic records of the damage and the loss of life caused by earthquakes go back only 100 years, but they show that in the period between 1926 and 1950, over 350,000 people were killed and the damage to buildings and public works totaled nearly 10,000 million US Dollars. On the average, more than 10,000 persons die every year because of earthquakes; see Figure 1.

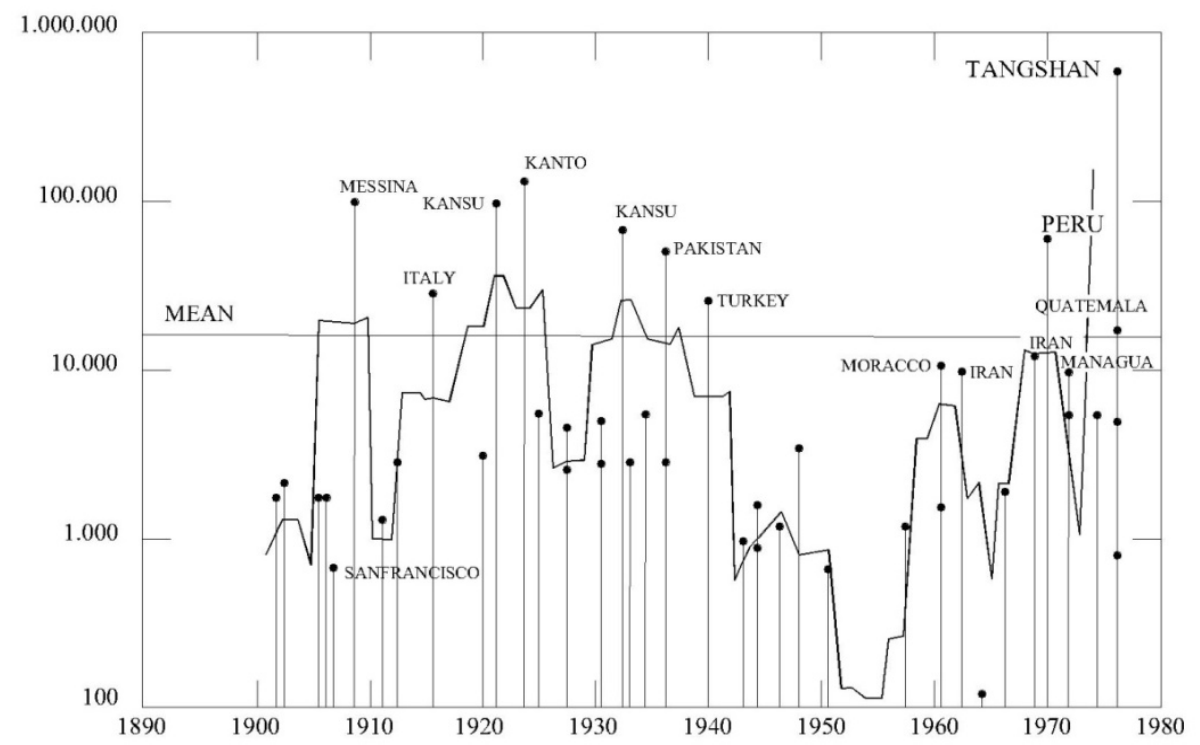

\section{Figure 1: Loss of Life Caused by Major Earthquakes ${ }^{[7]}$}

From the study of the immense volume of seismological data collected during the past sixty years, the pattern of distribution of earthquakes over the world has emerged quite clearly. Two principal seismic belts may be distinguished: the Circum-Pacific Belt extending around the shores of that ocean from New Zealand to Chile; and the Mediterranean-Alpine Belt, extending from Morocco, through the Mediterranean and the Middle East into Central and South-East Asia. Other belts of activity are associated with 
rift systems such as the East African rift valley, see Figs. 1-2 of refernce ${ }^{[7]}$. Within these main belts, recent research has revealed the existence of detailed patterns of seismicity, knowledge of which is of great practical importance, since it permits a more precise delimitation of the zones in which earthquakes are likely to occur. Over sixty developing countries lie within these main seismic zones, and in them, seismic activity has had a significant impact on their economy. Developing countries generally have the following characteristics:

i. rabid growth of population in urban cities;

ii. these cities have been built on inadequate infrastructure;

iii. building codes and safety measures are usually not implemented in the design and construction of most structures;

iv. absence of emergency plans and well trained personnel who can properly act during the event of an earthquake;

v. Poor health care.

The recorded history of earthquake in many developing countries shows that there are numerous essential structures which were constructed on sites where there is a probability of major earthquake occurrence. Experiences with catastrophic earthquake consequence have shown that the earthquake itself doesn't have to cause severe damage and injuries. The degree of catastrophic damage depends on the built-in materials and the type of structures. To prevent future catastrophic, codes of seismic design and construction should be elaborated and put into effect. The building codes should also consider:

i. Reconstruction and repair earthquake damaged structures;

ii. Strengthening and conservation of existing buildings to comply with seismic design and construction conditions.

Specialized responsible authorities should permanently control the efficient application of codes. The application of proven technologies of earthquake-resistant design and construction raises building costs in a proportion depending on the maximum expected seismic intensity, on the type of construction and on local economic factors. Typical figures for the percentage of increase in cost vary from 3 to 5 per cent in the case of large reinforced concrete structures up to 15 to 20 per cent in the case of small buildings in zones of high seismic intensity. Nevertheless, apart from the fundamental importance of saving human life, such additional capital costs are more than offset in the long run by the saving of reconstruction expenses 
and by the avoidance of the economic losses due to interruption of productive activities by earthquake damage.

In order to reduce these costs to the minimum compatible with public safety, it is a general practice to divide each country into three or more seismic zones, according to the maximum seismic intensity to be expected. The promulgation and enforcement of antiseismic building codes and regulations present problems of particular difficulty to developing countries:

i. The technical needs are not clearly defined.

ii. The detailed seismicity of many developing countries has to be investigated by seismologists.

iii. Social and economic factors make it difficult to establish a reliable system of inspection and enforcement.

Since 1952, considerable progress has been achieved in the field of earthquake engineering particularly during the last 25 years, when new calculation methods, have been introduced by employment of modern computer systems and experimental testing on structural components and full-scale structures. Even though, many developing countries are still have very little or no professional and educational staff who are specialized in seismology and in earthquake engineering. The absence of such technical staff made the local authorities, in these countries, not to be aware of the danger of earthquakes. On the way for compensating the deficiency in this technical staff, every year some 25 engineers from different developing countries were being invited to attend a short course in seismic design and construction of buildings. This course was being held annually in Skopje, Macedonia. Beside the technical advantage of these courses, many participants may be for the first time in their professional life, meet engineers from other countries and have opportunity to share knowledge and transfer information. The active growth of seismology and earthquake engineering in modern times has led also a number of countries in the Middle East, South-East Asia and Latin America to send students to Japan to avail themselves of the special facilities offered by the various universities and institutions in that country. However, in view of the effective return of such courses, other countries and organizations should take steps towards establishing similar courses.

Geotechnical and structural engineers, seismologists and architects, in seismic born developing countries, are urgently asked to conduct serious research works in order to:

i. establish details of the seismotectonics of their countries; 
ii. assess ground motion records and accurate attenuation relations for sites which include high population and/or sensitive structures like dams, bridges, main water treatment plants, and power generating stations;

iii. develop local recommendations for earthquake resistant design, which complies with the local nature of each region.

\section{Nature and Characteristics of Earthquakes:}

\subsection{Nature of Earthquakes:}

An earthquake is a phenomenon during which strong vibrations occur in the ground due to release of enormous energy within a short period of time, causing sudden disturbance in the earth's crust and the upper mantle. The maximum quantity of energy released in one earthquake event is about 0.001 times the total heat energy released by the earth surface in one year ${ }^{[2]}$. The location in which the earthquake originates is called the focus of the earthquake or the hypocenter. The vertical projection of the focus on the earth surface is named the epicenter. In general, the focus can be an extended volume of any irregular size and shape. In such a case, the epicenter can be considered as the center of the projected surfacial region of the focus. However, epicenters are always points on the earth's surface with their geographical location given in terms of longitudes and latitudes.

Many phenomena may give rise to earthquakes: volcanic activity, explosions, collapse of caves... etc. from engineering standpoint of far most importance are the earthquakes of tectonic origin. These earthquakes are usually associated with large strains in the earth's crust. It is worthwhile mentioning that, there is no part of the world that is completely free of earthquakes, i.e. earthquakes can strike anywhere at any time, with varying magnitude and intensity. Earthquakes are inevitable, and unfortunately, with the present state of knowledge neither their location and time of occurrence nor their magnitude and duration are predictable. Nevertheless, many seismologists used to depend partially on the following observational phenomena to forecast earthquakes: unusual rise and fall of water levels in wells; changes in the magnetic fields; abnormal behavior of animals ... etc. The surface amplitude of the earthquakes, at first, shows a slight tremor which then instantly and abruptly increases. This second portion of motion continues for some time, thenafter, it gradually decays. The first portion of slight trembling is called "the initial tremor", the next part; characterized 
with large amplitudes, is called "the main tremor", and the last portion is "the tail tremor". There are two main types of seismic waves, generated at the hypocenter during any earthquake event; namely, primary longitudinal or dilatational waves, and secondary transverse or distortive waves. Primary waves are usually faster that secondary ones. Since the velocities of these waves are known, the time of their arrival at different seismograph stations will determine the location of the epicenter and the time of the earthquake occurrence.

\subsection{Earthquake magnitude:}

The magnitude of an earthquake represents the amount of strain energy liberated at the hypocenter of the earthquake and thus determines the degree of local deformation caused. Nowadays, Richter's magnitude scale is used universally. In its original definition, the magnitude, $M$, is evaluate according to the following equation:

Where:

$M=\frac{\log A}{A_{0}}$

Where,

$A=$ the earthquake amplitude;

$A_{0}=$ calibration amplitude, usually equals $0.001 \mathrm{~mm}$.

The largest magnitude of earthquake ever recorded is in the order of 8.9 (Japan, $1906^{[1,7]}$, and Lisbon, Portugal $1755^{[1,7]}$ ). Earthquakes of magnitude 2.0 or less generally have no effect on buildings.

\subsection{Earthquake intensity:}

The term "seismic intensity" is used to denote the severity of an earthquake at a particular location. With increasing epicenteral distance, the severity of an earthquake normally decreases. Hence, severe earthquakes would be associated with various intensity values. The earthquake intensity also depends on: the geological structure of earth between the epicenter and the place of observation; and on the local site conditions at that place. Earthquake intensity is measured by several intensity scales. The most famous scale is the Modified Mercalli Scale, usually abbreviated as MM. The MM scale has 12 levels of intensity; see e.g. reference ${ }^{[1]}$. 


\section{Earthquake Design of Structures:}

Earthquake resistant buildings should be designed and constructed according to the following safety criteria:

i. For minor level earthquakes, which can be expected to occur more frequently, structural and nonstructural elements should not suffer any damage.

ii. For events of moderate intensity, structural elements can suffer slight damage, without exhausting their post elastic behavior.

iii. For infrequent strong earthquakes, the structure or parts of them should not collapse. Repairable and economically justified damage should be expected in many structures.

However, it should be considered that earthquakes are of random nature. Also, there are many problems related to the determination of the structural response to seismic excitations. Hence, the structural damage level cannot be completely eliminated. Seismologists and structural engineers usually aim to reduce the damage level to the extent that human injuries and losses are eliminated. The damage degree would decrease with decrease of seismic intensity and increase of frequency of earthquake occurrence. On the bases of the above concepts for seismic design of structures, earthquake damage can be controlled by following appropriate procedures for the analysis, design and construction of buildings which are subjected to earthquake forces.

The equivalent static lateral force procedure is nowadays being adopted by several codes of practice in many countries. The Uniform Building Code, UBC of the International Conference of building Official, was safely accepted in USA and suggested for to be used several developing countries, since it is direct and easy to apply ${ }^{[3],[17]}$. The UBC was first enacted by the International Conference of building Officials at the sixth Annual Business Meeting in Arizona, USA, in the year 1927.

In the UBC the seismic zone in which a structure is located determines permissible structural systems. Seismic zones are regions in which seismic ground motion, corresponding to a certain probability of occurrence, is within certain ranges, e.g. the United States is divided into Seismic Zones 0 through 4 , with 0 indicating the weakest earthquake ground motion, and 4 indicating the strongest.

The most recent development in structural classification has been the establishment of Seismic Design Categories as the determinant of seismic 
detailing requirements. Recognizing that building performance during a seismic event depends not only on the severity of sub-surface rock motion, but also on the type of soil upon which a structure is founded, the SDC is a function of location, building occupancy, and soil type.

The Federal Emergency Management Agency (FEMA) of USA has contracted the Building Seismic Safety Council (BSSC) to develop the National Earthquake Hazards Reduction Program (NEHRP) Provisions for new buildings. One of the primary goals of the program is to reduce or mitigate losses from earthquakes. The NEHRP Recommended Provisions for Seismic Regulations for New Buildings are recommended provisions that have increasingly been adopted in recent times by model codes and standards.

Comparisons between the 1997 NEHRP Provisions and the UBC are made on the basis of seismic provisions, material design provisions, foundation design requirements, quality assurance provisions, and nonstructural element design requirements. In the comparisons, the UBC is judged equivalent if its provisions are equivalent to, or more stringent than, the corresponding requirements in the 1997 Provisions. The UBC is judged not equivalent if the requirements of the 1997 NEHRP Provisions are more stringent than the requirements in the model code ${ }^{[11]}$.

The International Building Code, IBC, is a model code that provides minimum requirements to safeguard the public health, safety and general welfare of the occupants of new buildings and structures. The 2009 IBC adopted procedure to determine seismic loads similar to the NEHRP provisions, see chapter 16 of reference ${ }^{[8]}$.

In view of the above, this paper suggests the NEHRP provisions to be adopted by Sudan and many other developing countries. Attempting to brainstorm and draw the attention of engineers and seismologist to the importance of the issue, hereinafter, is a brief description of the terms and the procedure suggested for evaluating seismic forces on structures.

\section{General Procedure}

4.1 Seismic Use Groups

All structures shall be assigned to one of the following Seismic Use Groups:

Seismic Use Group III. Structures for this group are those having essential facilities that are required for post-earthquake recovery and those containing substantial quantities of hazardous substances. 
Seismic Use Group II. Structures here are those that have a substantial public hazard due to occupancy.

Seismic Use Group I. Seismic Use Group I structures are those not assigned to Seismic Use Groups III or II.

\subsection{Seismic Design Category}

All structures shall be assigned to a Seismic Design Category based on their Seismic Use Group and the design spectral response acceleration parameters, $S_{D S}$ and $S_{D 1}$. Each structure shall be assigned to the more severe Seismic Design Category determined in accordance with Tables 1 and 2, irrespective of the fundamental period of vibration of the structure, $T$.

Table 1: Seismic Design Category Based on $S_{D S}$

\begin{tabular}{|c|c|c|l|}
\hline \multicolumn{3}{|c|}{ Seismic Use Group } & \multirow{2}{*}{ Value of $\boldsymbol{S}_{\boldsymbol{D S}}$} \\
\hline III & II & I & \\
\hline $\mathrm{A}$ & $\mathrm{A}$ & $\mathrm{A}$ & $S_{D S}<0.167$ \\
\hline $\mathrm{C}$ & $\mathrm{B}$ & $\mathrm{B}$ & $0.167 \leq S_{D S}<0.33$ \\
\hline $\mathrm{D}$ & $\mathrm{C}$ & $\mathrm{C}$ & $0.33 \leq S_{D S}<0.50$ \\
\hline $\mathrm{D}^{\mathrm{a}}$ & $\mathrm{D}^{\mathrm{a}}$ & $\mathrm{D}^{\mathrm{a}}$ & $0.50 \leq S_{D S}$ \\
\hline${ }^{a}$ See footnote to Table 1.4-2. \\
\hline
\end{tabular}

Table 2: Seismic Design Category Based on $S_{D 1}$

\begin{tabular}{|c|c|c|c|}
\hline \multicolumn{3}{|c|}{ Seismic Use Group } & \multirow{2}{*}{ Value of $S_{D 1}$} \\
\hline III & II & I & \\
\hline $\mathrm{A}$ & $\mathrm{A}$ & A & $S_{D 1}<0.067$ \\
\hline $\mathrm{C}$ & $\mathrm{B}$ & B & $0.067 \leq S_{D 1}<0.133$ \\
\hline $\mathrm{D}$ & $\mathrm{C}$ & $\mathrm{C}$ & $0.133 \leq S_{D 1}<0.20$ \\
\hline $\mathrm{D}^{\mathrm{a}}$ & $\mathrm{D}^{\mathrm{a}}$ & $\mathrm{D}^{\mathrm{a}}$ & $0.20 \leq S_{D 1}$ \\
\hline \multicolumn{4}{|c|}{$\begin{array}{l}{ }^{a} \text { Seismic Use Group I and II structures located on sites with } S_{1} \text { greater } \\
\text { than or equal to } 0.75 \text { shall be assigned to Seismic Design Category E } \\
\text { and Seismic Use Group III structures located on such sites shall be } \\
\text { assigned to Seismic Design Category F. }\end{array}$} \\
\hline
\end{tabular}

\subsection{Site Classification for Seismic Design}

The site class is determined according to the soil properties as explained in Clause 3.5 of reference ${ }^{[5]}$.

The Site Classes are generally defined as follows: 

A Hard rock
B Rock
C Very dense soil and soft rock.
D Stiff soil.
E Soft clay.
F Soils requiring site-specific evaluations.

\subsection{Site-Specific Procedure}

For each region of developing countries a site-specific study shall account for the regional tectonic setting, geology, and seismicity, the expected recurrence rates and maximum magnitudes of earthquakes on known faults and source zones, the characteristics of ground motion attenuation, near-fault effects if any on ground motions, and the effects of subsurface site conditions on ground motions. The study shall incorporate current scientific interpretations, including uncertainties, for models and parameter values for seismic sources and ground motions.

Probabilistic maximum considered earthquake. Where site-specific procedures are utilized, the probabilistic maximum considered earthquake ground motion shall be taken as that motion represented by a 5-percentdamped acceleration response spectrum having a 2 percent probability of exceedance in a 50 year period.

Deterministic maximum considered earthquake. The deterministic maximum considered earthquake spectral response acceleration at each period shall be taken as 150 percent of the largest median 5-percent-damped spectral response acceleration computed at that period for characteristic earthquakes on all known active faults within the region.

This paper suggests maps of Maximum Considered Earthquake for Sudan based on probabilistic maximum considered earthquake ground motion. The suggested maps are obtained in the light of the findings of Abdalla et. al. ${ }^{[2]}$ and Sudan seismicity catalogue ${ }^{[4]}$ bearing in mind some incidents of destructive earthquakes occurred at South Kurdofan State, see Figures 3 and 4.

Mapped acceleration parameters. The parameters $S_{S}$ and $S_{1}$ shall be determined from the respective $0.2 \mathrm{sec}$ and $1.0 \mathrm{sec}$ spectral response accelerations, see e.g. Figures 2 and 3 suggested for Sudan.

Site coefficients and adjusted acceleration parameters. The maximum considered earthquake (MCE) spectral response acceleration parameters $S_{M S}$ 
and $S_{M 1}$, adjusted for site class effects, shall be determined using Eq. 2 and 3 , respectively:

and

$$
S_{M S}=F_{a} S_{S}
$$$$
S_{M 1}=F_{v} S_{1}
$$

where $F_{a}$ and $F_{v}$ are defined in Tables 3.3-1 and 3.3-2, respectively.

Table 3: Values of Site Coefficient $F a$

\begin{tabular}{|c|c|c|c|c|c|}
\hline \multicolumn{5}{|c|}{$\begin{array}{l}\text { Mapped MCE Spectral Response Acceleration Parameter at } 0.2 \\
\text { Second Period }^{a}\end{array}$} & \multirow{2}{*}{$\begin{array}{l}\text { Site } \\
\text { Class }\end{array}$} \\
\hline$S_{S} \geq 1.25$ & $S_{S}=1.00$ & $S_{S}=0.75$ & $S_{S}=0.50$ & $S_{S} \leq 0.25$ & \\
\hline 0.8 & 0.8 & 0.8 & 0.8 & 0.8 & A \\
\hline 1.0 & 1.0 & 1.0 & 1.0 & 1.0 & B \\
\hline 1.0 & 1.0 & 1.1 & 1.2 & 1.2 & $\mathrm{C}$ \\
\hline 1.0 & 1.1 & 1.2 & 1.4 & 1.6 & $\mathrm{D}$ \\
\hline 0.9 & 0.9 & 1.2 & 1.7 & 2.5 & $E$ \\
\hline$-^{b}$ & $-^{b}$ & $-^{b}$ & $-^{b}$ & $-^{b}$ & $\mathrm{~F}$ \\
\hline
\end{tabular}

Table 4: Values of Site Coefficient $F_{v}$

\begin{tabular}{|c|c|c|c|c|c|}
\hline \multicolumn{5}{|c|}{$\begin{array}{l}\text { Mapped MCE Spectral Response Acceleration Parameter at } 1 \text { Second } \\
\operatorname{Period}^{a}\end{array}$} & \multirow{2}{*}{$\begin{array}{l}\text { Site } \\
\text { Class }\end{array}$} \\
\hline$S_{1} \geq 0.5$ & $S_{1}=0.4$ & $S_{1}=0.3$ & $S_{1}=0.2$ & $S_{1} \leq 0.1$ & \\
\hline 0.8 & 0.8 & 0.8 & 0.8 & 0.8 & A \\
\hline 1.0 & 1.0 & 1.0 & 1.0 & 1.0 & B \\
\hline 1.3 & 1.4 & 1.5 & 1.6 & 1.7 & $\mathrm{C}$ \\
\hline 1.5 & 1.6 & 1.8 & 2.0 & 2.4 & $\mathrm{D}$ \\
\hline 2.4 & 2.4 & 2.8 & 3.2 & 3.5 & $\mathrm{E}$ \\
\hline$--^{b}$ & $-{ }^{b}$ & $--^{b}$ & $-^{b}$ & $-^{b}$ & $\mathrm{~F}$ \\
\hline
\end{tabular}

Design acceleration parameters. The parameters $S_{D S}$ and $S_{D 1}$ shall be determined from Eq.3.3-3 and 3.3-4, respectively: 


$$
S_{D S}=\frac{2}{3} S_{M S}
$$

and,

$$
S_{D_{2}}=\frac{2}{3} S_{M 2}
$$

Design response spectrum. Where a design response spectrum is required by NEHRP Provisions and site-specific procedures are not used, the design response spectrum shall be developed as indicated in Figure 2. where:

$S_{a}=$ the design spectral response acceleration at any period.

$S_{D S}=$ the design spectral response acceleration parameter at short periods.

$S_{D 1}=$ the design spectral response acceleration parameter at 1 second period.

$T=$ the fundamental period of the structure (sec) obtained from analysis models.

$T_{0}=0.2 S_{D 1} / S_{D S}$

$T_{S}=S_{D 1} / S_{D S}$

$T_{L}=$ Long-period transition period, $T_{L}$ maps are to be developed for each region by geological authorities.

This paper suggests some Long-period transition Period Maps, base on the geological composition, to be used for Sudan for instant until more accurate maps are developed, see Figure 5.

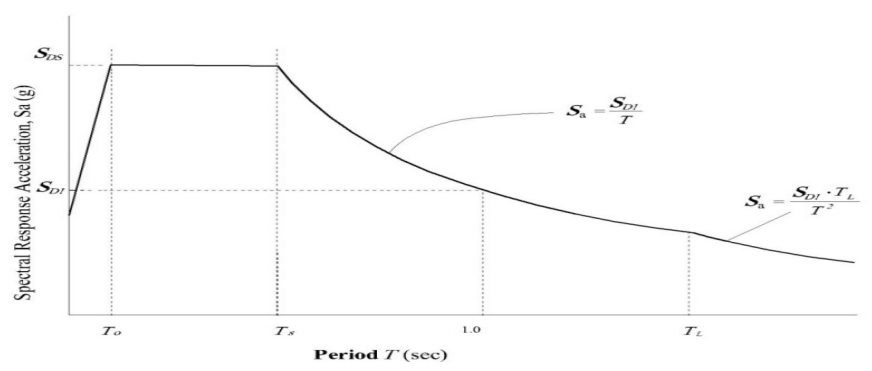

Figure 2: Design Response Spectrum

Period determination. The fundamental period of the building, $T$, in the direction under consideration shall be established using the structural 
properties and deformational characteristics of the resisting elements in a properly substantiated analysis.

Approximate fundamental period, $T_{a}$, in seconds, shall be determined from the following equation:

$$
T_{a}=C_{r} h_{n}^{x}
$$

where $h_{n}$ is the height in meters above the base to the highest level of the structure and the values of $C_{r}$ and $x$ shall be determined from Table 5.

Table 5: Values of Approximate Period Parameters $C_{r}$ and $x$

\begin{tabular}{|c|c|l|}
\hline$x$ & $C_{r}$ & \multicolumn{1}{c|}{ Structure Type } \\
\hline 0.80 & 0.0724 & $\begin{array}{l}\text { Moment resisting frame systems of steel in which the frames } \\
\text { resist 100 percent of the required seismic force and are not } \\
\text { enclosed or adjoined by more rigid components that will prevent } \\
\text { the frames from deflecting where subjected to seismic forces. }\end{array}$ \\
\hline 0.90 & 0.0466 & $\begin{array}{l}\text { Moment resisting frame systems of reinforced concrete in which } \\
\text { the frames resist 100 percent of the required seismic force and are } \\
\text { not enclosed or adjoined by more rigid components that will } \\
\text { prevent the frames from deflecting where subjected to seismic } \\
\text { forces. }\end{array}$ \\
\hline 0.75 & 0.0731 & $\begin{array}{l}\text { Eccentrically braced steel frames and buckling restrained } \\
\text { braced frames }\end{array}$ \\
\hline 0.75 & 0.0488 & All other structural systems \\
\hline
\end{tabular}

Other formulae for determining approximate fundamental period, $\mathrm{Ta}$, in seconds, for frames and masonry structures are also permitted see Section 5.2.2 of reference ${ }^{[5]}$.

Table 6 shows summery of the process leading to the classification of the Seismic Design Category ${ }^{[9]}$. 
Table 6: Process Leading to Classification of SDC

\begin{tabular}{|c|c|c|}
\hline $\begin{array}{c}\text { Column } 3 \\
\begin{array}{c}\text { Consider long-period } \\
\text { ground motion }\end{array} \\
\end{array}$ & $\begin{array}{c}\text { Column } 2 \\
\begin{array}{c}\text { Consider short-period } \\
\text { ground motion }\end{array} \\
\end{array}$ & Step \\
\hline \multirow[t]{2}{*}{$\begin{array}{l}\text { At } 1 \text { second period, } S_{1} \\
\text { (Site Class B) }\end{array}$} & $\begin{array}{l}\text { At short period, } S_{S} \\
\text { (Site Class B) }\end{array}$ & $\begin{array}{l}\text { Determine spectral response } \\
\text { accelerations from contour } \\
\text { maps* }\end{array}$ \\
\hline & & $\begin{array}{l}\text { Determine site class: } \\
\text { If no data available }\end{array}$ \\
\hline use site class D & use site class D & $\begin{array}{l}\text { Determine site coefficient } \\
\text { for acceleration or velocity }\end{array}$ \\
\hline$F_{v}($ Table 4$)$ & $F_{a}($ Table 3$)$ & $\begin{array}{l}\text { Determine soil-modified } \\
\text { spectral response } \\
\text { acceleration }\end{array}$ \\
\hline$S_{M 1}=F_{v} S_{1}$ & $S_{M S}=F_{a} S_{S}$ & $\begin{array}{l}\text { Calculate the design spectral } \\
\text { response acceleration }\end{array}$ \\
\hline$S_{D 1}=2 / 3 S_{M 1}$ & $S_{D S}=2 / 3 S_{M S}$ & $\begin{array}{l}\text { Determine seismic use } \\
\text { group (SUG) of structure }\end{array}$ \\
\hline See paragraph 4 & See paragraph 4 & $\begin{array}{l}\text { Determine seismic design } \\
\text { category }\end{array}$ \\
\hline $\begin{array}{l}\text { A, B, C, or D* as a } \\
\text { function of SUG } S_{D 1} \\
\text { from Table } 2\end{array}$ & $\begin{array}{l}\mathrm{A}, \mathrm{B}, \mathrm{C}, \text { or } \mathrm{D}^{*} \text { as a } \\
\text { function of SUG } S_{D S} \\
\text { from Table } 1\end{array}$ & Choose most severe SDC \\
\hline $\begin{array}{l}\text { Compare Column } 2 \mathrm{w} \\
\text { line }\end{array}$ & Column 3 from previous & \\
\hline
\end{tabular}

\subsection{Equivalent Lateral Force Procedure}

An equivalent lateral force analysis shall consist of the application of equivalent static lateral forces to a linear mathematical model of the structure. The lateral forces applied in each direction shall sum to a total seismic base shear, $V$, in that direction which is determined in accordance with the following equation:

$$
V=C_{s} W
$$

where:

$C_{s}=$ the seismic response coefficient determined in accordance with Sec. 5.2.1.1 and 
$W=$ the total dead load and applicable portions of other loads.

The seismic response coefficient, $C_{s}$, shall be determined in accordance with the following equation:

where:

$$
C_{s}=\frac{S_{S D}}{\frac{R}{T}}
$$

$S_{D S}=$ the design spectral response acceleration parameter in the short period range as determined from Sec. 3.3.3,

$R=$ the response modification factor. Table 7 shows value of $R$ for different seismic force resisting system commonly available in most developing countries, and

$I=$ the occupancy importance factor determined in accordance with Table 8.

Vertical distribution of seismic forces. The lateral force, $F_{x}$, induced at any level shall be determined from the following equations:

$$
F_{x}=C_{v x} V
$$

and

$$
C_{w x}=\frac{W_{x} h_{x}^{k}}{\sum_{i=1}^{\mathrm{m}} h_{i}^{k}}
$$

where:

$C_{v x} \quad=$ vertical distribution factor,

$V=$ total design lateral force or shear at the base of the structure,

$w_{i}$ and $w_{x}=$ the portion of the total gravity load of the structure, $W$, located or assigned to Level.

$h_{i}$ and $h_{x}=$ the height from the base to Level $i$ or $x$, and

$k=$ an exponent related to the effective fundamental period of the structure as follows:

For structures having a period of 0.5 seconds or less, $k=1$

For structures having a period of 2.5 seconds or more, $k=2$ For structures having a period between 0.5 and 2.5 seconds, $k$ shall be determined by linear interpolation between 1 and 2 or may be taken equal to 2 . 


\subsection{Further Precautions for Seismic Design:}

Among many other precautions, it is most important that, every building or structure shall be designed to resist overturning moments resulting from any applied lateral forces. Also, the lateral deflection or drift of a story relative to its adjacent stories shall not exceed 0.005 times the story height unless it can be demonstrated that greater drift can be tolerated ${ }^{[8]}$. For further limitations regarding, seismic groups, $T, C_{S}, S_{1}, S_{S}$, the reader can refer to reference ${ }^{[5]}$,

\section{Table 7: Response Modification Factor for Common Basic Seismic- Force-Resisting Systems Available in Developing Countries}

\begin{tabular}{|c|c|c|c|}
\hline \multirow{2}{*}{$\boldsymbol{R}$} & Basic Seismic-Force-Resisting System & \multirow{2}{*}{$\boldsymbol{R}$} & Basic Seismic-Force-Resisting System \\
\hline & Building Frame Systems & & Bearing Wall Systems \\
\hline 8 & $\begin{array}{l}\text { Steel eccentrically braced frames with moment- } \\
\text { resisting } \\
\text { connections at columns away from links } \\
\text { Buckling-restrained braced frames, moment- } \\
\text { resisting beam-column connections } \\
\text { Composite eccentrically braced frames }\end{array}$ & 6.5 & Light-frame walls with shear panels \\
\hline 7 & $\begin{array}{l}\text { Steel eccentrically braced frames with non- } \\
\text { moment-resisting } \\
\text { Buckling-Restrained Braced Frames, non- } \\
\text { moment resisting beam-column connections } \\
\text { Special steel plate shear walls }\end{array}$ & 5 & Special reinforced concrete shear walls \\
\hline 6.5 & Composite steel plate shear walls & 4 & $\begin{array}{l}\text { Ordinary reinforced concrete shear walls } \\
\text { Intermediate precast shear walls } \\
\text { Light-frame walls with diagonal braces }\end{array}$ \\
\hline 6 & $\begin{array}{l}\text { Special steel concentrically braced frames } \\
\text { Special reinforced concrete shear walls } \\
\text { Special composite reinforced concrete shear } \\
\text { walls with steel elements }\end{array}$ & 3.5 & Special reinforced masonry shear walls \\
\hline 5 & $\begin{array}{l}\text { Ordinary steel concentrically braced frames } \\
\text { Ordinary reinforced concrete shear walls } \\
\text { Intermediate precast shear walls } \\
\text { Composite concentrically braced frames } \\
\text { Ordinary composite reinforced concrete shear } \\
\text { walls with steel elements }\end{array}$ & 3 & Ordinary precast shear walls \\
\hline 4 & Ordinary precast shear walls & 2 & $\begin{array}{l}\text { Detailed plain concrete shear walls - } \\
\text { Ordinary reinforced masonry shear walls } \\
\text { Detailed plain masonry shear walls }\end{array}$ \\
\hline 3 & Ordinary composite braced frames & 2.5 & $\begin{array}{l}\text { Intermediate reinforced masonry shear } \\
\text { walls }\end{array}$ \\
\hline 2.5 & Detailed plain concrete shear walls & 1.5 & $\begin{array}{l}\text { Ordinary plain concrete shear walls } \\
\text { Ordinary plain masonry shear walls } \\
\text { Prestressed masonry shear walls }\end{array}$ \\
\hline 1.5 & Ordinary plain concrete shear walls & & \\
\hline
\end{tabular}


Table 8: Occupancy Importance Factor, $I$

\begin{tabular}{|c|c|}
\hline $\boldsymbol{I}$ & Seismic Use Group \\
\hline 1.00 & I \\
\hline 1.25 & II \\
\hline 1.50 & III \\
\hline
\end{tabular}

\section{Sudan Experience with Earthquake Engineering}

Although the Sudan is not one of the high seismically active regions of the world, there is a resent organized increase in seismic activity concerning seismicity of Sudan and earthquake engineering. During the last 150 years many sever earthquakes hit various places in Sudan ${ }^{[4]}$. The highest of all are of magnitude 7.0 and 7.1 on Richter scale hit areas of the far south-east; while the latest in list hits the urban capital but of scale 5.5. Very minor damage was recorded, as a result of these earthquakes, since most of affected areas were remote and lightly populated. But still there is a recognizable probability that one large earthquake may hit a highly populated site in the country. Abdalla et. al. ${ }^{[1],[2]}$ making use of the historical and instrumental earthquake catalogue of the Sudan, are probably the first who assessed seismic hazard and seismic zoning of the Sudan on base of probabilistic approach. At a later date $\mathrm{Abu}$ Bakr et. al. ${ }^{[3]}$, suggested provisions for earthquake resistant design of structure for Sudan. The suggested provisions are based on the UBC procedure. Geologists and seismology of Sudan, in fact they brought the attention of the engineers to the importance of the consideration of seismic loads in the design and construction works in Sudan. In the past few years, intensive research work leading to the enforcement of this type of load in the analysis and design of structure was started as follows:

i. In the main three universities that graduate most of the Sudanese civil engineers; namely: University of Khartoum, Omdurman Islamic University, and Sudan University of Science and Technology; an intent was made to include coursers like structure dynamic and earthquake engineering in the syllabi of the final year and postgraduate levels.

ii. Preparation of seismic zoning map of Sudan is ongoing. The suggested seismic zoning maps reflect the seismic data of the region in the past 150 years. 
iii. Modern approaches of seismic hazard and seismic risk analysis, with the help of values of peak ground accelerations, were being followed in the way of establishing the seismic category map for Sudan, see reference ${ }^{[2]}$.

iv. Establishment of strong bases for regulations of seismic design and construction of buildings, in accordance with Sudan local conditions.

\section{Conclusions}

The disastrous effect of earthquakes in developing countries is a direct consequence of the demolition of buildings which have been usually constructed without any consideration of the effect of seismic forces.

Because of the random nature of earthquakes and the problems related to the determination of the actual structure response to seismic excitation, the structural damage, during the event of an earthquake, cannot be completely avoided. However, by following appropriate seismic design procedure, the damage level can be reduced to the extent that human injuries and losses are eliminated.

Civil engineers, from developing countries, who attend international short courses on seismic design and construction of buildings, will substantially promote the earthquake engineering in their countries.

Sudan has stepped forwards towards the conclusion of its own regulations for seismic design and construction of buildings.

Developing countries, which lie within seismically active regions, are urgently asked to:

i. Increase the number of their native seismic engineers, if required;

ii. Construct regional macro seismic zoning maps.

iii. NEHRP provisions, because they are clear and direct, are recommended to be one of the bases for the preparation of preliminary specifications for seismic design in many developing countries. It is required to adjust the different coefficients for evaluating the seismic forces to match with the local conditions of each region. 


\section{References}

[1] Abdalla, Jamal A. et. al. "Seismotectonics and Seismic Zoning of Sudan", Sudan Engineering Society Journal, Vol.43, No. 34, January 1997, pp. 1-15.

[2] Abdalla, Jamal A. et. al. "Seismic Hazard Assessment and Zoning of Sudan”, Sudan Engineering Society Journal, Vol.44, No. 35, June 1997, pp. $34-50$.

[3] Abu Bakr A. Wahab et. al. "Suggested Procedure for Earthquake Resistant Design of Structures for the Sudan", Building and Road Research Journal, Vol. 2, August 1999, pp. 36 - 46.

[4] Ambraseys, N. N. and Adams, R. D. "Seismicity of the Sudan", Bulletin of the Seismological Society of America. No. 76, pp. 483-493.

[5] Building Seismic Safety Council, "NEHRP Recommended Provisions for Seismic Regulations for New Buildings and Other Structures (FEMA 450)", Part 1: Provisions, 2003 Edition. National Institute of Building Sciences, Washington, D.C.USA.

[6] Emilia J. "Seismic Effects on Structures", Elsevier, Amsterdam. 1991.

[7] Farzad Naeim, "The Seismic Design Handbook", Second Edition, Kluwer Academic Publishers, USA, 2001.

[8] Ghosh, S. K. "Comparison of the Seismic Provisions of the 1997 Uniform Building Code to the 1997 NEHRP Recommended Provisions" A report to: Building and Fire Research Laboratory National Institute of Standards and Technology Gaithersburg, MD 20899, February 2001.

[9] Ghosh, S. K. et. al. "Seismic Design Considerations in Model Codes", Masonry Today, October 2000.

[10] Ghosh, S. K. and Madhu Khuntia "Impact of Seismic Design Provisions: Comparison with 1997 UBC”, SEAOC 1999 Convention, pp. 229-254.

[11] International Building Code, International Code Council Inc., Illinois, USA, 2009.

[12] Milutinoyic, Zoran. "Basic Principles in the Seismology and Earthquake Engineering", Institute of Earthquake Engineering and Engineering Seismology, University of Kiril and Metodi, Skopje, Macedonia. 1988. 
[13] Ngu Kik Koong and Loew Ket Won, "Earthquake Hazards and Basic Concepts of Seismic Resistant Design of Structures", Master Builders, $4^{\text {th }}$ quarter 2005, pp 90-95.

[14] Parish, Scott. "Uniform Building Code Compliance Manual: 1997", Uniform Building Code, McGraw Hill, New York. 1999.

[15] UNESCO, international Decade for National Disaster Reduction, 1990.

[16] UNESCO/UNDP, "Special Fund Component Report Series: International Institute of Seismology and Earthquake Engineering, Tokyo, Japan", Report prepared for the Government of Japan by the UNESCO for the period 1963-1968.

[17] Uniform Building Code, International Conference of Building Officials, Whittier, California, USA, 1997.

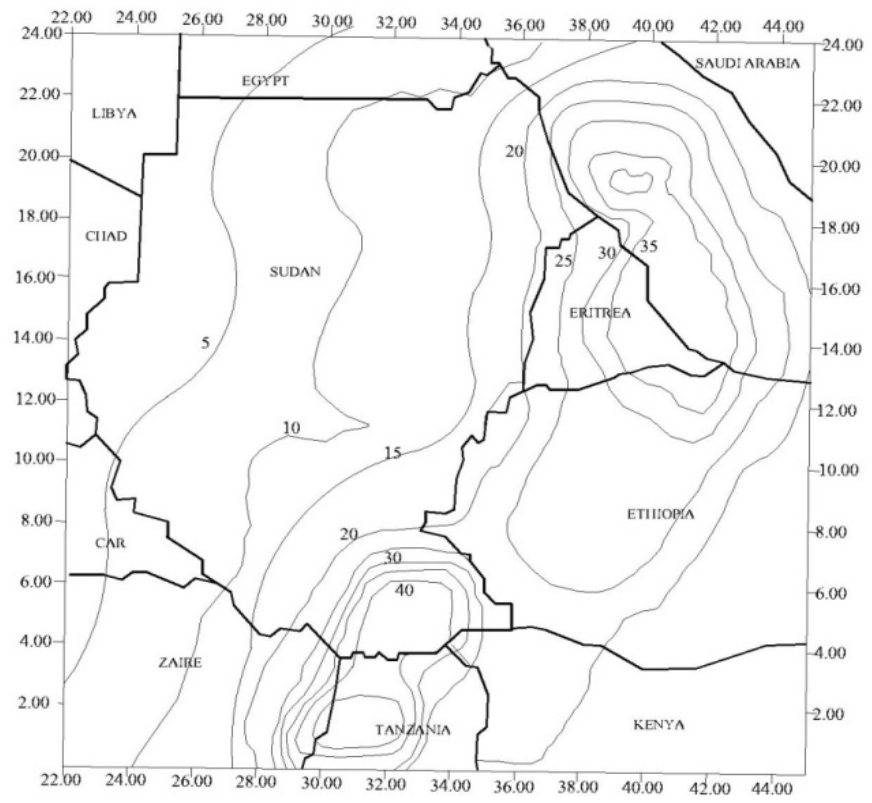

Figure 3 : Suggested Maximum Consider Earthquake Ground Motion for Sudan of 0.2 sec Spectral Response Acceleration, Site Class B (Contour intervals in \%g, $\mathrm{g}=$ gravitational acceleration) 


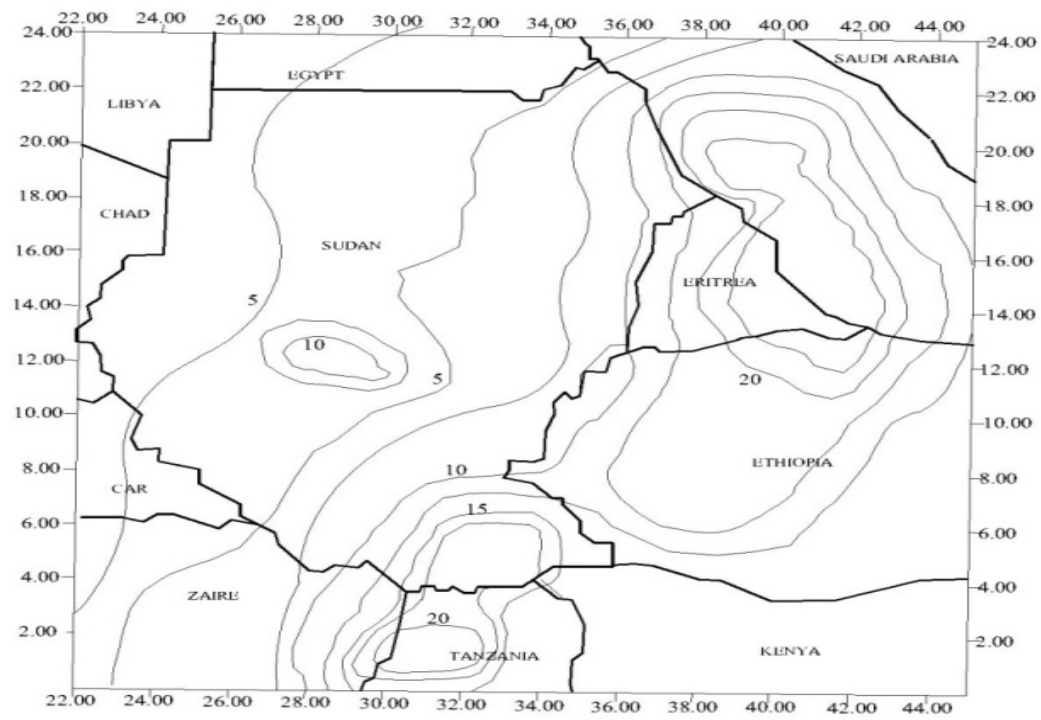

Figure 4: Suggested Maximum Consider Earthquake Ground Motion for Sudan of 1.0 sec Spectral Response Acceleration, Site Class B (Contour intervals in \%g, $\mathrm{g}=$ gravitational acceleration)

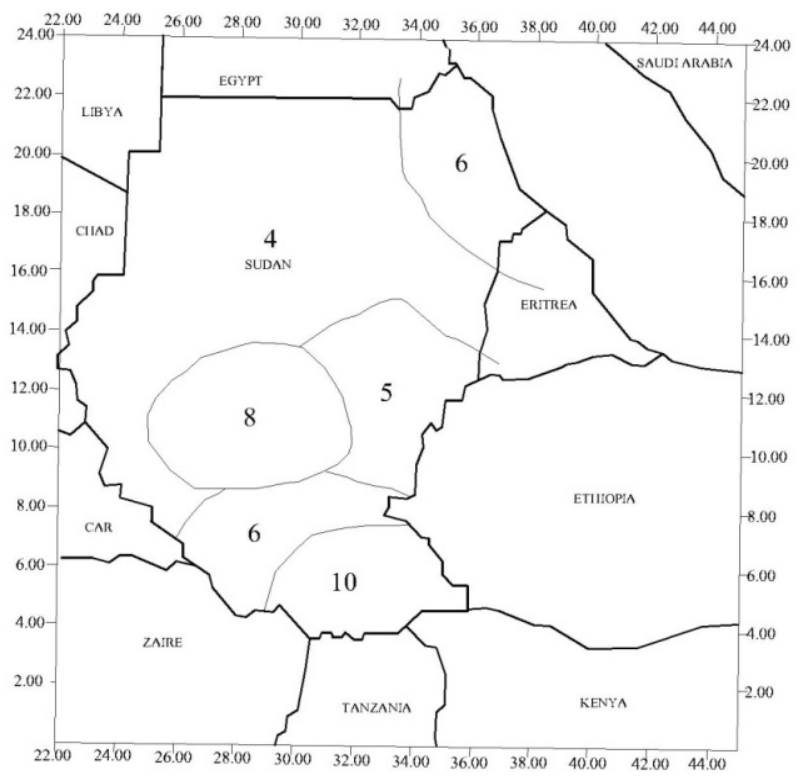

Figure 5: Long Period Transition Period Suggested for Sudan 